\title{
The Value of Using Grey Scale Ultrasound in the Estimation of Palpable Breast Lumps in a Specialist Breast Clinic in Mosul City of Iraq
}

\author{
Marwa Ismail khalaf* , Israa Basheer Abd Allah** \\ *Department of Radiology , Collage of Medicine , University of Mosul \\ **Department of Radiology , Al-Khansaa Hospital , Nineveh-Health Office , Mosul , Iraq \\ Correspondence: marwaesmail85_radio@uomosul.edu.iq
}

(Ann Coll Med Mosul 2021; 43 (1):29-34).

Received: 30 $0^{\text {th }}$ Janu. 2021; Accepted: $14^{\text {th }}$ April 2021.

\begin{abstract}
Background: Breast carcinoma is one of the most common female malignancies affecting the females within the 30-60 years age groups in many parts of the world. The aim of the study was to assess the using of grey scale ultrasound in the evaluation of palpable breast lumps in Mosul city and compare the finding with the histopathology.

Materials and Methods: The study was retrospective study which was done at Al-Khansa Specialist Breast Clinic, from January 2019 to July 2019. 155 patients with palpable breast lump were evaluated by grey scale ultrasound and their characteristics radiological features were studied and compared with the final histopathological diagnosis.

Results: By ultrasound, about $60 \%$ of the cases were benign, $13.5 \%$ were intermediate and $26.4 \%$ were malignant compared with the histopathology which showed $71.6 \%$ were benign and $28.4 \%$ were malignant. The most common benign lesion was fibroadenoma while mastitis was the most common intermediate lesion diagnosed on histopathology. The specificity and sensitivity of the ultrasound in detection of breast carcinoma were $92.7 \%$ and $88.6 \%$ respectively. PPV of $82.9 \%$ and NPV of $95.3 \%$ with diagnostic accuracy $91.6 \%$.

Conclusion: In our study, the grey scale ultrasonography has high specificity, sensitivity and diagnostic accuracy in detection of breast carcinoma to reduce the morbidity and mortality of the disease. In general, ultrasound' $s$ availability and low cost in developing countries and comfort to the patients with no radiation effect; making it considered as $1^{\text {st }}$ line investigation modality in females breast lumps.
\end{abstract}

Keywords: Ultrasound, palpable breast masses, breast carcinoma .

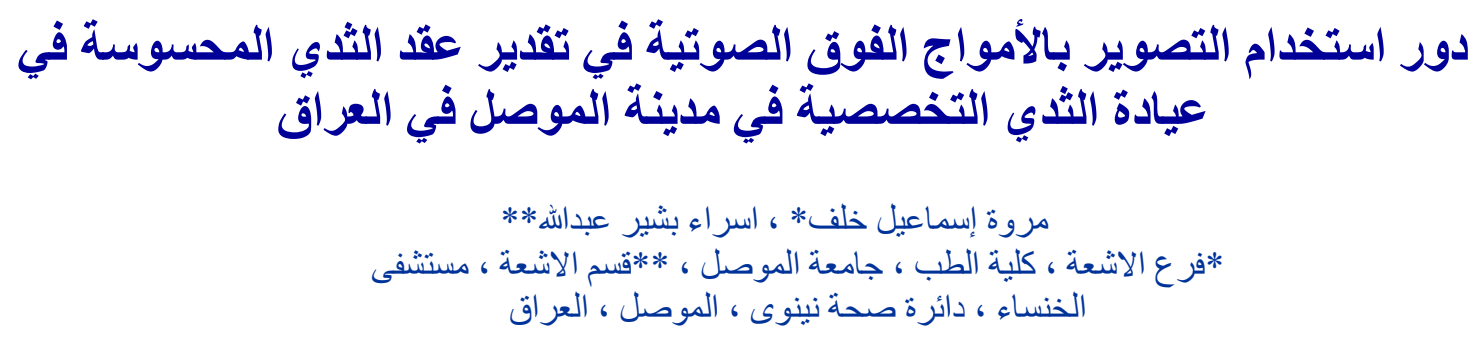

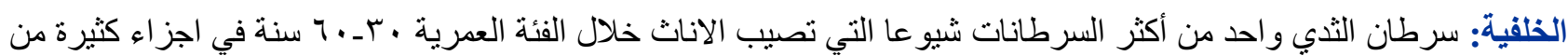
العالم. الهدف من الدراسة كان لتقييم استخدام التصوير بالأمواج الفوق الصوتية في تقييم عقد الثذي المحسوسة في مدينة الموصل ومقارنتها مع التشخيص النسيجي المرضئ التراني.

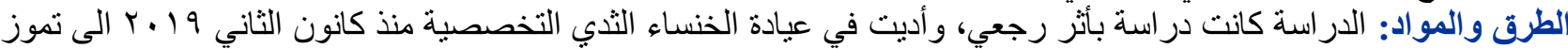

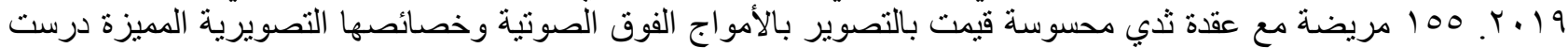

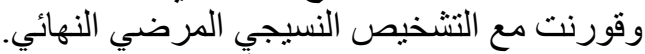

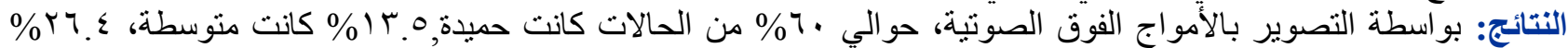

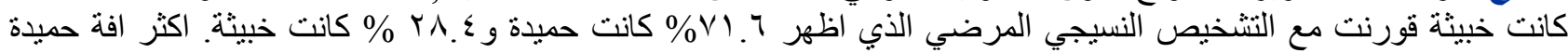


كانت ورم غدي ليفي بينما التهاب الثدي كان أكثر افة متوسطة شخصت بالتشريح النسيجي المرضي. النوعية و الحساسية للتصوير

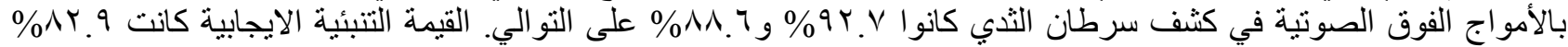

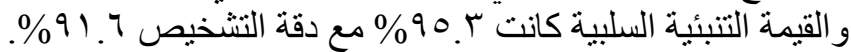

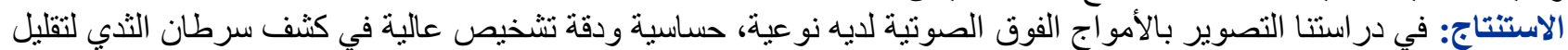

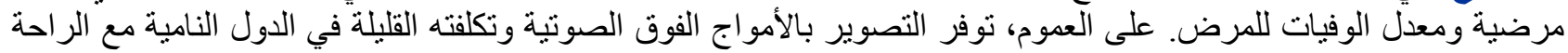

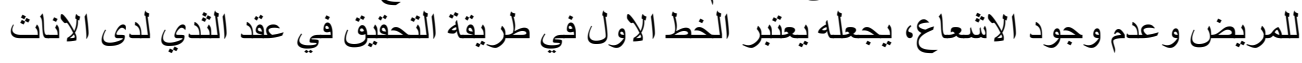

$$
\text { الكثمات المفتاحية: الامواج الفوق الصوتية، كتل الثدي المحسوسة، سرطان الثدي. }
$$

\section{INTRODUCTION}

- lobally, 1 million new breast carcinoma 7 cases each year are diagnosed ${ }^{1}$. Breast cancer is the $2^{\text {nd }}$ most common cause of cancer. Correlated women mortality around the globe is $6.6 \%$ diagnosed at less than 40 years of age, $2.4 \%$ at less than 35 years \& $0.65 \%$ are at less than 30 years of age ${ }^{2,3}$. Therefore, to reduce mortality ,it is important to early diagnose and manage the breast masses. Ultrasound is used to assess patients presented with palpable breast lumps as a $1^{\text {st }}$ modality because of its basic advantages of its availability, non-invasive, low cost and comfortable to the patients .In addition to its ability to confirm the presence of the lesion , it also provide lesion characteristics.

Thus, the aim of this study was to find out the accuracy of the ultrasonography in diagnosing palpable breast lumps, its sensitivity and specificity in getting the malignant lesions in correlation with the findings of histopathology, to pick up the malignant lesions as early as possible to reduce mortality \& morbidity of the carcinoma of the breast.

\section{MATERIALS AND METHODS}

The study was cross sectional with retrospective evaluation of the data which collected from January 2019 to July 2019 over a period of seven months. The inclusion criteria's :1. all females with palpable breast lumps (with or without pain or nipple discharge), 2. whom underwent ultrasound assessment in the AL-KHANSA Specialist Breast Clinic were included in the study. The exclusion criteria's ${ }^{11}: 1$. those whom their histopathological diagnosis was not obtained and,2. those whom their diagnosis previously known were excluded from the study. Thus, a total of 155 cases with palpable breast lump and having histopathological diagnosis were finally studied. Ethical guidelines as required for human studies according to Health Institute in Nenava City were followed. Gray scale ultrasound examinations were done by a specialist radiologist using high frequency $(3-12 \mathrm{MHz})$ linear transducer (Philips Healthcare). Prior to the examination, an explanation about the procedure was given to the patient. Every female had both breasts systemically examined, both transverse and sagittal scans were performed radially from the nipple to the periphery in addition to the axilla looking for any lymphadenopathy. Breast Imaging Reporting And Data System (BIRADS) categories according to the BIRADS atlas $5^{\text {th }}$ edition $2013^{4}$ was used for reporting. BIRADS 2 and 3 were considered as benign, $4 \mathrm{a}$ and $4 \mathrm{~b}$ were intermediate, and $4 \mathrm{c}$ and 5 were considered as malignant lesions. Ultrasound features including margins, shape, orientation, posterior acoustic features, micro calcifications were analyzed. On the basis of these features a primitive diagnosis was made from ultrasonography while final diagnosis was made by histopathology from the Department of pathology which considered as the gold standard. The histopathological diagnosis was obtained with core biopsy, using histological classification of breast cancer subtypes based on architectural features and growth patterns and using the Tumor-Node-Metastasis (TNM) based staging. According to the final pathological results, the lesions were typed as benign and malignant. The results were entered to a computer and data analysis was done using simple statical tools and SPSS 16.

\section{RESULTS}

The sample includes 155 patients, the age group ranges (17-72) years, with average age was (43.483), those in the benign group were (41.08) and malignant group were (51.09), the age range of patients with malignancy was $(26-72)$ years and 9 patients $(5.8 \%)$ younger than 40 years.

The presence of palpable lump was the presenting symptom in $90 \%(n=139)$ of women, followed by lump and pain in $7 \%(n=11)$ and lump with nipple discharge in $3 \%(n=5)$. The lesion was detected in the left breast in $53 \%(n=82)$, in the right side in $41.2 \% \quad(n=64)$ and both breasts involvement was found in $5.8 \%$ of cases $(n=9)$. Among the cystic lesions $(n=40)$, the ultrasound accuracy in diagnosis of cystic masses was 
$92 \%(n=37)$. According to the BIRADS atlas $5^{\text {th }}$ edition $2013^{4}$, On ultrasonography , $60 \%$ of cases $(n=93)$ were benign, $13.5 \%$ of cases $(n=21)$ were intermediate and $26.4 \%$ of cases $(n=41)$ were malignant , while histopathological diagnosis showed $71.6 \% \quad(n=111)$ were benign and $28.4 \%(n=44)$ were malignant as shown on (table 1).The sensitivity \& specificity of the ultrasound in detection of the breast malignancy was $88.6 \%$ and $92.7 \%$ respectively, with PPV of $82.9 \%$, NPV of $95.3 \%$ and diagnostic accuracy $91.6 \%$.

Table 1 : showing the malignant, intermediate and benign diagnosis on ultrasound and histopathological diagnosis

\begin{tabular}{|c|c|c|c|}
\hline $\begin{array}{c}\text { Ultrasound } \\
\text { classification }\end{array}$ & $\begin{array}{c}\text { Histopatholo } \\
\text { gically } \\
\text { benign }\end{array}$ & $\begin{array}{c}\text { Histopatholo } \\
\text { gically } \\
\text { malignant }\end{array}$ & No. \\
\hline Benign & 88 & 5 & 93 \\
\hline Intermediate & 15 & 6 & 21 \\
\hline Malignant & 8 & 33 & 41 \\
\hline Total & 111 & 44 & 155 \\
\hline
\end{tabular}

The final histopathological diagnosis is showed in the pie chart (figure 1), in which the benign neoplastic group were 39 lesions $(25.1 \%)$ of which the most common was fibroadenoma, example shown in (figure 2), while 40 cases (25.8\%) were benign proliferative lesions of which fibrocystic disease was the most as a case shown in (figure 3 ) . 5 cases (3.2\%) typed as benign on ultrasound and were found to be malignant on histopathology. Regarding the lesions categorized as intermediate by the ultrasound, $71.4 \% \quad(n=15)$ of them were found to be benign, of which the most common diagnosis was mastitis $(n=10) .8$ lesions $(19.5 \%)$ were falsely typed as malignant on ultrasound of which diagnosis as:

4 fibroadenoma ,2 mastitis, 1 antibioma and 1 Paget disease on histopathology.

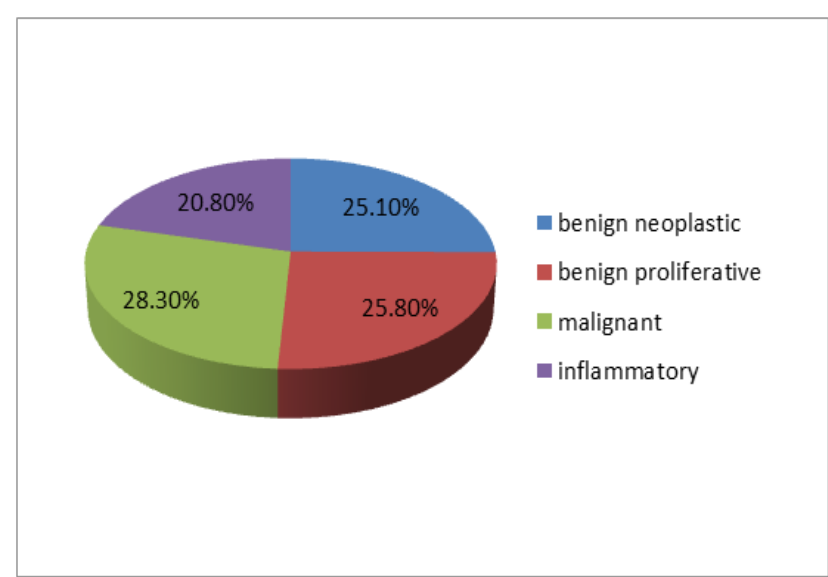

Figure 1: Pie chart show the distribution of the final histopathological groups.

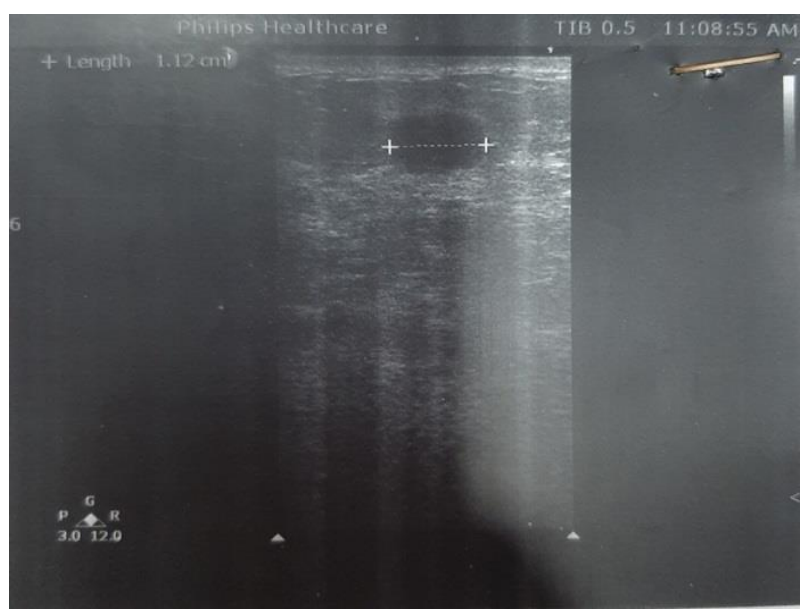

Figure 2: fibroadenoma. a well circumscribed oval hypoechoic lesion, the long axis orientation parallel to the skin surface, no micro-calcification and no posterior shadowing.

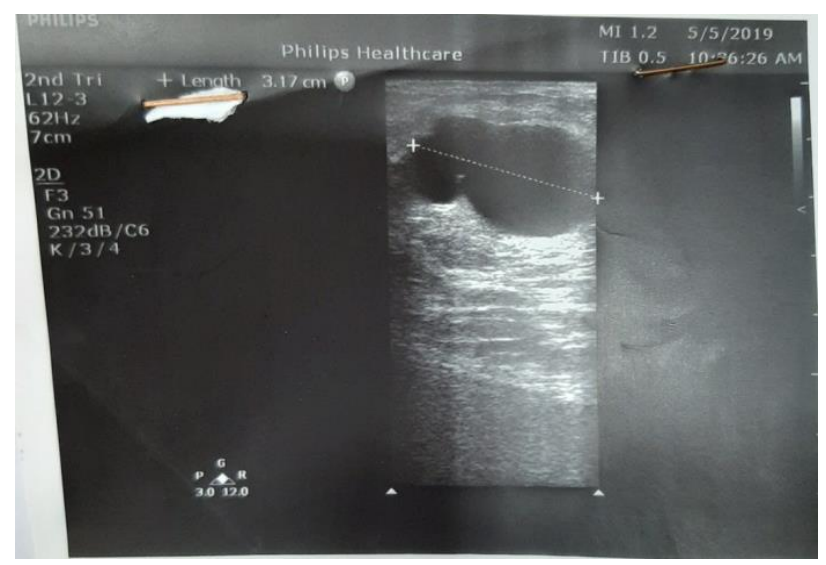

Figure 3: fibrocystic changes. a well-defined anechoic cystic lesion with posterior acoustic enhancement (increased echoes deep to the lesion due to well transmit sound waves) . 
A correlation of ultrasound BIRADS categories and their pathological diagnosis revealed that number of malignant increased with higher BIRADS categories (figure 4).

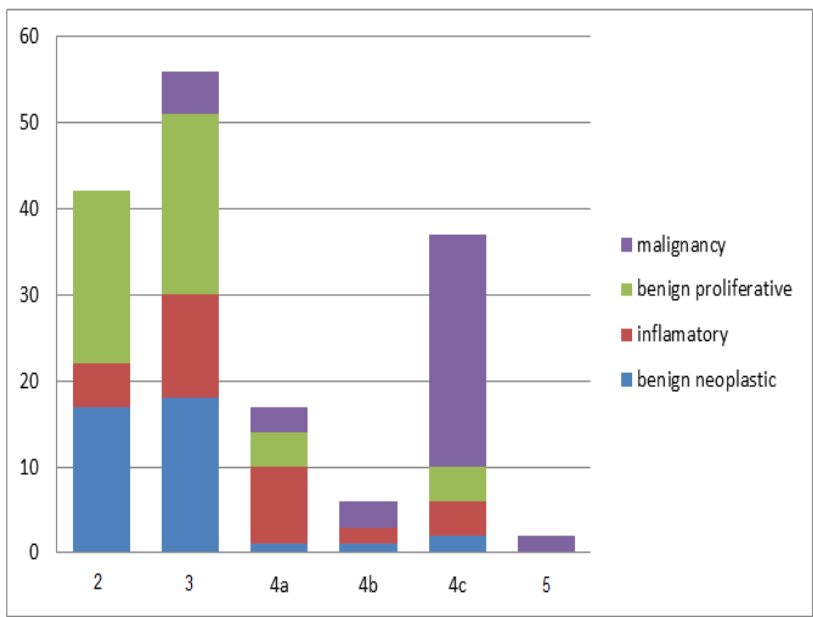

Figure 4: Bar chart shows correlation of the ultrasound BIRADS categories and the pathological diagnosis.

Among $93 \%(n=41)$ of malignant lesions were hypoechoic, $70 \%(\mathrm{n}=31)$ had irregular shape as case shown in (figure 5), and $50 \%(n=22)$ had posterior shadowing. No malignant lesion was hyperechoic.

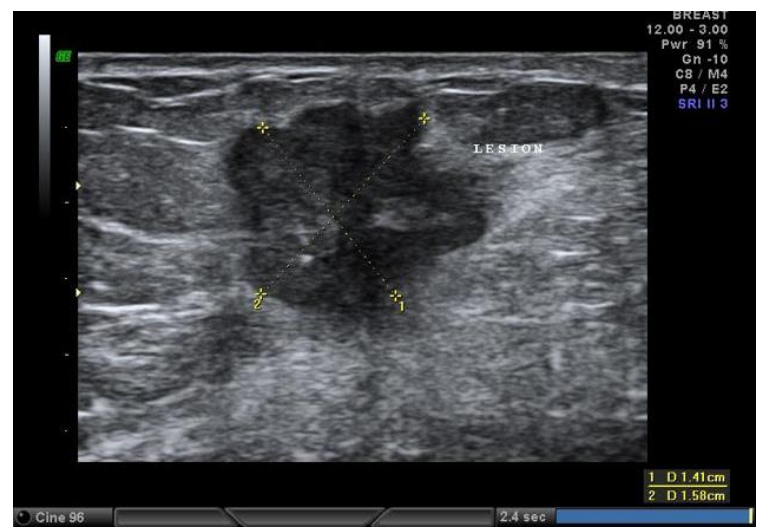

Figure 5: invasive ductal carcinoma. A welldefined hypoechoic speculated mass, contain micro-calcifications.

While $73 \%(n=82)$ of which were benign lesions were hypoechoic, $75 \% \quad(n=85)$ were well defined margins, $66 \%(n=74)$ of lesions had oval shape and only $5 \&(n=6)$ had posterior shadowing. No benign lesion had micro-calcification. The sonographic characteristics of benignity or malignancy revealed significant correlation with final histopathological diagnosis $(P$ value $<0.01)$ and are summarized in table (2).
Table 2: show the frequency of the different ultrasonic features in malignant and benign lesions

\begin{tabular}{|c|c|c|c|}
\hline $\begin{array}{l}\text { Sonographic } \\
\text { features }\end{array}$ & & $\begin{array}{c}\text { Number } \\
(\%) \text { of } \\
\text { benign } \\
\text { cases }\end{array}$ & $\begin{array}{c}\text { Number } \\
(\%) \text { of } \\
\text { malignant } \\
\text { cases }\end{array}$ \\
\hline \multirow[t]{4}{*}{ shape } & oval & $\begin{array}{c}74 \\
(66.6 \%)\end{array}$ & $9(20.4 \%)$ \\
\hline & rounded & $\begin{array}{c}21 \\
(18.9 \%)\end{array}$ & 1 (2.2\%) \\
\hline & irregular & $\begin{array}{c}12 \\
(10.8 \%)\end{array}$ & $\begin{array}{c}31 \\
(70.4 \%)\end{array}$ \\
\hline & complex & $4(3.6 \%)$ & $3(6.8 \%)$ \\
\hline \multirow[t]{4}{*}{ margins } & $\begin{array}{c}\text { Well } \\
\text { circumscribed }\end{array}$ & $\begin{array}{c}85 \\
(75.5 \%)\end{array}$ & $3(6.8 \%)$ \\
\hline & indistinct & $10(9 \%)$ & $\begin{array}{c}8 \\
(18.1 \%)\end{array}$ \\
\hline & speculated & $4(3.6 \%)$ & $\begin{array}{c}13 \\
(29.5 \%)\end{array}$ \\
\hline & $\begin{array}{c}\text { micro } \\
\text { lobulated }\end{array}$ & $\begin{array}{c}12 \\
(10.8 \%)\end{array}$ & $\begin{array}{c}20 \\
(45.4 \%)\end{array}$ \\
\hline \multirow[t]{4}{*}{ Echogenicity } & hyperechoic & $4(3.6 \%)$ & 0 \\
\hline & isoechoic & $6(5.4 \%)$ & $1(2.2 \%)$ \\
\hline & Hypoechoic & $\begin{array}{c}82 \\
(73.8 \%)\end{array}$ & $\begin{array}{c}41 \\
(93.1 \%)\end{array}$ \\
\hline & $\begin{array}{l}\text { Heterogeneou } \\
\text { s }\end{array}$ & $\begin{array}{c}19 \\
(17.1 \%)\end{array}$ & $2(4.5 \%)$ \\
\hline \multirow{3}{*}{$\begin{array}{l}\text { Posterior } \\
\text { acoustic } \\
\text { features }\end{array}$} & Shadow & $6(5.4 \%)$ & $22(50 \%)$ \\
\hline & Enhancement & $\begin{array}{c}65 \\
(58.5 \%)\end{array}$ & $\begin{array}{c}14 \\
(31.8 \%)\end{array}$ \\
\hline & Absent & $40(36 \%)$ & $\begin{array}{c}8 \\
(18.1 \%)\end{array}$ \\
\hline \multirow[t]{2}{*}{ Orientation } & Parallel & $\begin{array}{c}100 \\
(90 \%)\end{array}$ & $11(25 \%)$ \\
\hline & Not parallel & $11(10 \%)$ & $33(75 \%)$ \\
\hline \multirow[t]{2}{*}{$\begin{array}{c}\text { micro } \\
\text { calcification }\end{array}$} & Absent & $\begin{array}{c}111 \\
(100 \%)\end{array}$ & $\begin{array}{c}30 \\
(68.1 \%)\end{array}$ \\
\hline & Present & 0 & $\begin{array}{c}14 \\
(31.1 \%)\end{array}$ \\
\hline
\end{tabular}




\section{DISCUSSION}

Breast carcinoma is the second most common cause of cancer related to women mortality around the globe with disease incidence of $6.6 \%$ in patients younger than 40 years ${ }^{2,3}$. In addition to increased number of breast cancer cases, the recent studies show shift of the disease to the younger women. In Nepal, females underage of 40 years form about a quarter of all breast cancer cases ${ }^{5}$. The early diagnosis of breast cancer has good prognosis with an overall five-year survival rate more than $90 \%{ }^{6}$ \& reduce mortality around $18-29 \%{ }^{1}$.

In Iraq, ultrasound services are inexpensive cost in comparison with other investigations, therefore; it has been widely used in whole country even the rural areas. Thus, they form a crucial role in evaluation of palpable breast lumps.

The ultrasound features of malignant \& benign lesion had been evaluated by many studies. The study of Stavros et al. demonstrated the basis of sonographic findings of breast solid lesions ${ }^{7}$. The ultrasound findings of malignant and benign breast solid lesion of different studies are shown in table 3 $7-9$

\begin{tabular}{|c|c|}
\hline \multicolumn{2}{|c|}{$\begin{array}{c}\text { Table 3: ultrasound findings of malignant \& benig } \\
\text { breast solid lesions }\end{array}$} \\
\hline $\begin{array}{l}\text { Angular/speculated } \\
\text { margins }\end{array}$ & $\begin{array}{l}\text { Well circumscribed } \\
\text { smooth marains }\end{array}$ \\
\hline Internal hypoechogenisty & $\begin{array}{l}\text { Hyperechoic, } \\
\text { isoechoic or mild } \\
\text { hypoechoic }\end{array}$ \\
\hline $\begin{array}{l}\text { Irregular shape/wide less } \\
\text { than tall }\end{array}$ & $\begin{array}{l}\text { Oval shape/tall less } \\
\text { than wide }\end{array}$ \\
\hline Multiple microlobulations & 2 or 3 lobulations \\
\hline micro calcifications & $\begin{array}{l}\text { Echogenic thin } \\
\text { pseudo capsule }\end{array}$ \\
\hline Branch/duct extension & \\
\hline Posterior shadow & \\
\hline
\end{tabular}

The incidence of breast lumps in female of reproductive ages is $65 \%$, such a finding is nearly found out in Gonzoga . Et al ${ }^{10}(60 \%)$. Nearly two third $(71.4 \%)$ of intermediate lesions were being benign on histopathology with majority being mastitis (66.6\%), such finding compared to Anamika et al ${ }^{11}$ which report (91\%) of intermediate lesions by ultrasound were benign with mastitis is the most common lesion.

In this study, among the most benign lesion $(30.6 \%)$ proved on histopathology were fibroadenoma followed by fibrocystic diseases
(22.5\%), a finding compared to a research in the western india $^{12}$ which found the most common benign lesion was fibroadenoma (77.6\%) \& fibrocystic diseases (4.3\%). In this study, the diagnostic accuracy of sonography is $(79.2 \%)$ for benign lesion and (75\%) for malignant lesion which is comparative to a study of Malik R RS et al ${ }^{1}$. which found diagnostic accuracy $(71.42 \%)$ for benign lesions and (75\%) for malignant lesion.

Thus, from this study, we make a conclusion that ultrasound is more readily diagnose benign masses with sensitivity of $(91.6 \%)$, such an observation compared to Mansoor et $\mathrm{al}^{13}$ whom show sensitivity of $(81.8 \%)$ and Fleisher et $\mathrm{al}^{14}$ with sensitivity of $(89 \%)$. The ultrasound accuracy in diagnosis of cystic masses was (92\%) and has a significant role in differentiation of solid from cystic lesions such a finding is also reported in Gonzaga et $\mathrm{al}^{10}$, Anamika et al ${ }^{11}$ and Fleisher et al ${ }^{14}$.

The benign lesions, of which fibroadenoma is the most common, appear oval well circumscribed homogenous, wider than tall with variable acoustic appearance, such features are also reported by Rahbar et $\mathrm{al}^{15}$. Lipoma, one case was diagnosed and appeared as well circumscribed lesion with homogenous echogenicity same finding as Gao et al ${ }^{16}$ which found homogenous well defined echogenic lesion.

Regarding fibrocystic disease, the $2^{\text {nd }}$ most common finding in our study, range from single simple cyst to multiple cysts, in addition to 13 cases ductactasia and 2 cases galactocele

Regarding mastitis, whether bacterial including antibioma and abscesses; or non-bacterial including granulomatous mastitis. The appearance was various as irregular hypoechoic heterogeneous echogenicity or well-defined hypoechoic lesions, compared to Tan et al study ${ }^{17}$ which found various features ranging from irregular heterogeneous lesion, well defined tubular lesion to even normal finding. Most of cases of mastitis was interpreted as intermediate on ultrasound a similar finding reported in Anamika et al ${ }^{11}$. There were 6 cases of granulomatous mastitis, 3 antibioma and 7 abscesses, where 2 cases of mastitis and one antibioma were interpreted as malignant.

From the results of this study and other studies, it had been found that the ultrasound has a significant role in the breast masses evaluation. Thus, its use should be considered as initial investigation in most cases of palpable breast lumps especially in female of reproductive age as it is more accessible and low cost than mammography in the developing countries. In addition, ultrasound is directly related to the physical examination at the same time. 
From our study, it has been found that ultrasound of benefit in palpable breast mass characterization and play an important role in malignant mass detection as early as possible thus reduce mortality from breast carcinoma. The negative predictive value of ultrasound for breast carcinoma was high as reported by Harvey et al reported ${ }^{18}$ which showed high NPV.

\section{CONCLUSIONS}

As shown in our study, the grey scale ultrasonography has high specificity, sensitivity and diagnostic accuracy in detection of breast carcinoma to reduce the morbidity and mortality of the disease and to reduce the associated anxiety in patient having breast lumps. In general, ultrasound is available and has low cost in developing countries with no radiation effect and more comfortable for patients; it should be considered as $1^{\text {st }}$ line investigation modality especially in females under the age of 30 years. In addition to its benefit for ultrasound guided procedures as needle localization and lumpectomy to diagnose and treat early cases of breast carcinoma.

\section{REFERENCES}

1. Mallik R RS, Mandal A, Deoghuria D, Mandal SK,Bhattacharyya SK. Role of Ultrasonography in Non-Palpable Breast Lesion and Its Correlation with Fine Needle Aspiration Cytology and Histopathology. JMSCR 2014;2(5):1204-12. [Link]

2.Anders CK, Johnson R, Litton J, Phillips $M$, Bleyer A. Breast Cancer Before Age 40 Years. Semin Oncol.36(3):237-49. [PubMed]

3. Fredholm H, Eaker S, Frisell J, Holmberg L, Fredriksson I, Lindman H. Breast Cancer in Young Women: Poor Survival Despite Intensive Treatment. PLoS ONE. 2009;4(11). [Link]

4. Rao AA, Feneis J, Lalonde $\mathrm{C}$, Ojeda-Fournier $\mathrm{H}$. A. Pictorial Review of Changes in the BI-RADS Fifth Edition. Radiographics. 2016;36(3):623-39. [Link]

5. Nepal B SY, Sayami P, Sayami G. An institutional review of tumour biology of breast cancer in young Nepalese women. JSSN. 2017;18(2):16-9. [Link]

6. Sharma G, Dave R, Sanadya J, Sharma $P$, Sharma K. Various types and management of breast cancer: An overview. J Adv Pharm TechnolRes. 2010;1(2):109-26. [PubMed]

7.Stavros AT, Thickman D, Rapp CL, Dennis MA, Parker SH, Sisney GA. Solid breast nodules: use of sonography to distinguish between benign and malignant lesions. Radiology. 1995;196(1):12334. [Link]
8. Mainiero MB, Goldkamp A, Lazarus E, Livingston L, Koelliker SL, Schepps B, et al. Characterization of breast masses with sonography: can biopsy of some solid masses be deferred? J Ultrasound Med. 2005 Feb;24(2):161-7. [PubMed]

9. Gokhale S. Ultrasound characterization of breast masses. Indian J Radiol Imaging. 2009;19(3):242-7. [Link]

10. Gonzaga MA. How accurate is ultrasound in evaluatinn palpable breast masses? Pan Afr Med J. 2010; 7:1. [PubMed]

11. Anamika Jha, Benu Lohani. Sonography of palpable breast lumps in a tertiary health care centre in Nepal. Nepal Health Res Counc 2018 Oct-Dec;16(41):396-400.

12. Hatim KS, Laxmikant MS, Mulla T. Patterns and prevalence of benign breast disease in Western India. Int J Res Med Sci. 2017 Feb;5(2):684-688. [Link]

13. Mansoor T, Ahmed A, Syed $\mathrm{HH}$. Role of ultrasonography in the differential diagnosis of palpable breast lumps. Ind $J$ Surgery. 2002;64(6):499-501.

14. Fleischer AC, Muhletaler CA, Reynolds VH. Palpable breast masses: evaluation by high frequency handheld real-time sonography and xero-mammography. Radiology .1983;148:81317 this article on PubMed.

15. Rahbar G, Sie GC, Hansen GC. Benign versus malignant solid breast masses: US differentiation. radiology. 1999; 213:889-94. This article on PubMed

16. Gao Y, Slanetz PJ, Eisenberg RL. Echogenic Breast Masses at US: To Biopsy or Not to Biopsy? Radiographics. 2013;33(2):419-34. [Link]

17. Tan H, Li, R., Peng, W., Liu, H., Gu, Y., \& Shen, $X$. Radiological and clinical features of adult non-puerperal mastitis. $\mathrm{Br} \mathrm{J}$ Radiol. 2013;86(1024):20120657. [PubMed]

18. Harvey JA. Sonography of palpable breast masses. Semin ultrasound CT MR.2006;27(4):284-97. This article on PubMed. 